Doi: $\underline{\text { dx.doi.org/10.17921/2525-5320.2016.144-147 }}$

\title{
SABERES DOCENTES: NOVOS SUJEITOS E SUAS PRÁTICAS PEDAGÓGICAS
}

Eline Andrea Dornelas* - UEL

Palavras-chave: História. Ensino. Formação de Professores. Saberes Docentes.

\section{INTRODUÇÃO}

As ideias apresentadas nesta pesquisa procuram analisar de que forma as transformações ocorridas nos anos de 1990 em relação ao Ensino de História afetam a formação de professores licenciados em História. A literatura atual traz uma diversidade de abordagens teóricas e metodológicas na investigação dessa temática, destacando a preocupação e a compreensão como o conhecimento é construído pelo professor e utilizado em sala de aula. Como o professor se apropria das variadas ferramentas para estabelecer a relação da história e das fontes históricas que o auxilie nesse processo é um desafio para entendermos a articulação entre o pensar e o agir, a teoria e a prática, ou seja, como reelaboram as formas de pensar o processo de ensino e aprendizagem em História

O objetivo geral deste trabalho, como já mencionado, é compreender como o professor constrói seus saberes no diálogo com sua formação e com o seu trabalho em sala de aula.

\section{MATERIAL E MÉTODO}

A pesquisa por meio de narrativas foi o modelo de investigação escolhido por permitir ao pesquisador uma melhor compreensão de valores, opiniões, crenças, atitudes, visão de mundo e comportamento dos sujeitos investigados, consistindo em um caminho metodológico para as questões relacionadas aos professores e seus saberes bem como a complexidade no processo de formação docente.

Diante da abordagem de estudo selecionada, o instrumento utilizado para a

\footnotetext{
*E-mail: elinedornelas@gmail.com
} 
obtenção de dados da pesquisa foi o questionário, e os dados foram ordenados na seguinte estrutura: perfil, formação acadêmica e tempo de docência, e prática pedagógica. Para a coleta das informações, as respostas foram analisadas individualmente e depois agrupadas de acordo com a proximidade das respostas. Para o desenvolvimento da investigação, responderam o questionário sete professores do Fundamental I, II e Ensino Médio. Os professores puderam descrever o dia a dia da sala de aula e opinar sobre ele.

\section{RESULTADO E DISCUSSÃO}

Identificamos uma fragilidade no trabalho com as metodologias que advém da forma como as disciplinas pedagógicas são ministradas no curso de Licenciatura em História. Apesar das respostas dos docentes serem positivas quando questionados sobre a formação, esses dados não traduzem o posicionamento em outras questões. As respostas não foram muito claras sobre que entendimento possuíam sobre metodologia do ensino de História, ou seja, o conhecimento sobre a teoria do conhecimento de história, demonstrando certa fragilidade teórica e, às vezes, alguma confusão entre metodologia e técnica de ensino.

\section{CONCLUSÃO}

O resultado deste estudo gerou uma base de dados e a partir daí foi possível articular os domínios de conhecimentos mobilizados pelos professores durante suas ações pedagógicas, ou seja, seus saberes e fazeres. Abordar a formação docente e ensino de História significa repensar o contexto político, social, econômico e cultural, os avanços tecnológicos, e o novo perfil do professor na contemporaneidade.

\section{REFERÊNCIAS}

ABRAHÃO, M.H.M.B.; SOUZA, E.C. (Org.). Tempos, narrativas e ficções: a invenção de si. Porto Alegre: EDIPUCRS, 2006.

BARCA, I. Educação histórica: uma nova área de investigação. Rev. Faculdade Letras, v. 2, p.13-21, 2001.

BARCA, I. Educação histórica: uma nova área de investigação. In: ARIAS NETO, J. M. (Org.) Dez anos de pesquisas em ensino de história. Londrina: AtritoArt, 2005. p.1525. 
BARCA, I. Introdução: a educação histórica numa sociedade aberta. Currículo sem Fronteiras, v. 7, n.1, p.7, 2007. Disponível em: <http://www.curriculosemfronteiras.org/>. Acesso em: 12 maio 2016.

BITTENCOURT, C.M.F. O saber histórico na sala de aula. São Paulo: Contexto, 2002.

BITTENCOURT, C.M.F. Ensino de história: fundamentos e métodos. São Paulo: Cortez, 2004.

CAIMI, F.E. Uma mirada sobre o livro didático regional de história: o caso do Rio Grande do Sul. In: SIMPÓSIO NACIONAL DE HISTÓRIA, 24., 2007, São Leopoldo/RS. Anais... São Leopoldo/RS: Unisinos, 2007.

CAIMI, F.E. História escolar e memória coletiva: como se ensina? como se aprende? In: ROCHA, H. et al. (Org.) A escrita da história escolar: memória e historiografia. Rio de Janeiro: FGV, 2009.

CAIMI, F.E. A aprendizagem profissional no estágio curricular em história: mapeando características do desempenho competente na docência. ANPED SUL. SEMINÁRIO DE PESQUISA EM EDUCAÇÃO DA REGIÃO SUL, 9,. 2012, Caxias do Sul-RS. Anais... Caxias do Sul, 2012. p.1-13.

CAIMI, F.E. A licenciatura em História frente às atuais políticas públicas de formação de professores: um olhar sobre as definições curriculares. Rev. Latinoam. História, v.2, n.6, p.193-209, 2013.

CAMPOS, M.R. Profissão docente: novas perspectivas e desafios no contexto do século XXI. In: BALZANO, S. (Org.). O desafio da profissionalização docente no Brasil e na América Latina. Brasília: UNESCO, 2007.

CASTELLS, M. O poder da identidade. Paz e Terra, 1999.

CHARLOT, B. Da relação com o saber: elementos para uma teoria. Porto Alegre: Artes Médicas Sul, 2000.

CHARTIER, R. A história cultural: entre práticas e representações. Rio de Janeiro: Bertrand, 1990.

CIAMPI, H. A História pensada e ensinada: da geração das certezas à geração das incertezas. São Paulo: EDUC, FAPESP, 2000.

CUNHA, M.I. Conta-me agora! As narrativas como alternativas pedagógicas na pesquisa e no ensino. Rev. FEUSP, v.23, n.1/2, p.185-195, 1997.

CUNHA, M.I. Profissionalização docente: contradições e perspectivas. In: VEIGA, I.P.A. Desmistificando a profissionalização do magistério. Campinas: Papirus, 1999. p.127-147. 
CUNHA, M.I. Diferentes olhares sobre as práticas pedagógicas no ensino superior: a docência e sua formação. Educação, v.54, n.3, p.525-536, 2004.

DORNELAS, E. Patrimônio, museu e ação educativa. In: CONGRESSO INTERNACIONAL DE HISTÓRIA, 6, 2013. Disponível em: <http://www.cih.uem.br/anais/2013/trabalhos/383_trabalho.pdf.>. Acesso em: 15 jan. 2014.

FELDMANN, M.G. (Org.). Formação de professores e escola na contemporaneidade. São Paulo: Senac, 2009.

FINOCCHIO, S. Saberes e práticas com história: a formação docente na Argentina e o ensino de história. In: ZAMBONI, E. (Org.). Espaços de formação do professor de história. Campinas: Papirus, 2008.

FONSECA, T.N.L. O livro didático de História: lugar de memória e formador de identidades. In: SIMPÓSIO NACIONAL DE HISTÓRIA, 20, 1999, Florianópolis. Anais... São Paulo: Humanitas/FFLCH-USP/ANPUH, 1999. p.203-212.

FONSECA, S.G. A formação do professor de História no Brasil: novas diretrizes, velhos problemas. In: REUNIÃO DA ANPED, 24. 2007. Disponível em: <http://24reuniao.anped.org.br/tp.htm\#gt8>. Acesso em: 19 jul. 2016. 